\title{
KONDISI STRESS LANSIA DIMASA PANDEMI COVID-19 dan PENCEGAHANNYA
}

\author{
Cindy Minannisa / 191101089 \\ cindyminannisa01@gmail.com
}

\begin{abstract}
Abstrak
Sejak ditetapkan sebagai penularan wabah antar manusia di Wuhan, China pada 31 Desember 2019, infeksi coronavirus-2019 (COVID-19) yang menyebabkan penyakit Severe Acute Respiratory Syndrome - Coronavirus 2 (SARS-Cov-2) menjadi pandemi global. Dalam beberapa tahun terakhir, negara-negara telah berjuang dengan momentum yang meningkat untuk melawan wabah. Perjuangan ini membutuhkan implementasi efektif dari beberapa langkah yang diperlukan dalam ilmu kedokteran(Gokmen et al., 2021). Pandemi COVID-19 telah menimbulkan dampak kesehatan dan ekonomi yang belum pernah terjadi sebelumnya. Stres psikologis, kecemasan dan depresi memengaruhi tidak hanya pasien COVID-19 tetapi juga para profesional kesehatan, dan secara umum populasi. Takut tertular COVID-19, tindakan sosial restriktif yang dipaksakan, dan kesulitan ekonomi yang menyebabkannya trauma mental (Shrestha et al., 2020). Tujuan: untuk mengetahui tingkat stress lansia terhadap pandemic Covid-19 dan cara untuk menanganinya. Metode: Tugas ini menggunakan metode Literature review dimana dilakukan dengan cara menganalisis kajian dan eksplorasi jurnal, text book, maupun e-book yang relevan dan membahas tentang stress lansia dimasa pandemic Covid-19. Hasil: Hasil dari pengkajian ini dengan menggunakan metode literatur review adalah dengan membaca pengkajian ini pembaca dapat mengetahui bahwa pandemic Covid-19 sangat berpengaruh terhadap kesehatan mental lansia.
\end{abstract}

Kata Kunci: Covid-19, Lansia, Stres

\section{Abstract}

Since it was established as a human-to-human transmission outbreak in Wuhan, China on December 31, 2019, the coronavirus-2019 (COVID-19) infection which caused Severe Acute Respiratory Syndrome - Coronavirus 2 (SARS-Cov-2) has become a global pandemic. In recent years, countries have struggled with increasing momentum to fight the outbreak. This struggle requires the effective implementation of some of the steps required in medical science (Gokmen et al., 2021). The COVID-19 pandemic has had unprecedented 
health and economic impacts. Psychological stress, anxiety and depression affect not only COVID-19 patients but also healthcare professionals, and in general the population. Fear of contracting COVID-19, enforced restrictive social measures, and economic hardships that cause mental trauma (Shrestha et al., 2020). Purpose: to determine the stress level of the elderly against the Covid-19 pandemic and ways to deal with it. Methods: This assignment uses the Literature review method which is carried out by analyzing the study and exploration of relevant journals, text books, and e-books and discussing stress in the elderly during the Covid-19 pandemic. Results: The result of this study using the literature review method is that by reading this study the reader can find out that the Covid-19 pandemic has a very strong effect on the mental health of the elderly.

\section{Keywords: Covid-19, Elderly, Stress}

\section{Latar Belakang}

Diawal tahun 2020, dunia digemparkan dengan merebaknya virus baru yaitu Corona Virus jenis baru (SARSCov-2) dan penyakitnya disebut Coronavirus disease 2019 (COVID-19). Diketahui, asal mula virus ini berasal dari Wuhan, Tiongkok. Penularan virus ini ditengarai terkait dengan penjualan daging yang berasal dari binatang liar atau penangkaran hewan di pasar makanan laut (Cui, dkk., 2019). Ditemukan pada akhir Desember tahun 2019. Pada mulanya transmisi virus ini belum dapat ditentukan apakah dapat melalui antara manusiamanusia, tetapi jumlah kasus terus bertambah seiring waktu. Akhirnya dikonfirmasi bahwa transmisi pneumonia ini dapat menular dari manusia ke manusia (Relman, 2020). Sampai saat ini virus ini dengan cepat menyebar, masih misterius dan penelitian masih terus berlanjut.

Menularnya Covid-19 membuat dunia menjadi resah, termasuk di Indonesia. Covid-19 merupakan jenis virus yang baru sehingga banyak pihak yang tidak tahu dan tidak mengerti cara penanggulangan virus tersebut. Seiring mewabahnya virus Corona atau Covid19 ke ratusan negara, Pemerintah Republik Indonesia menerbitkan protokol kesehatan. Protokol tersebut akan dilaksanakan di seluruh Indonesia oleh pemerintah dengan dipandu secara terpusat oleh Kementerian Kesehatan RI (2020). (Telaumbanua, 2020)

Berbagai kebijakan pemerintah diberlakukan guna memperlambat penyebaran virus dimulai dari sering mencuci tangan, mengurangi menyentuh 
wajah, menggunakan masker di publik, physical distancing, hingga karantina mandiri (stay at home). Dengan jumlah kasus positif yang terus meningkat di Indonesia membuat pemerintah harus mengambil tindakan cepat demi keselamatan masyarakat luas, yaitu dengan memberlakukan karantina mandiri serta Pembatasan Sosial Berskala Besar (PSBB). (Roziika et al., 2020)

Pandemi penyakit coronavirus 2019 (COVID-19) adalah krisis kesehatan global yang sangat besar (Levkovich \& Shinan-Altman, 2020). Anjuran karantina mandiri telah dilaksanakan selama kurang lebih hampir satu tahun lamanya. Pembatasan aktivitas dan juga laju mobilitas masyarakat masih dilakukan. Tiga bulan bukanlah waktu yang singkat bagi para penggiat kerja, pelajar, dan bagi siapapun yang terbiasa beraktivitas di luar rumah. Masyarakat yang terbiasa melakukan aktivitas di luar rumah, kini tidak bisa merasakan kembali aktivitas tersebut selama kurang lebih tiga bulan belakangan ini. Namun, hal ini harus dilakukan oleh semua kalangan demi menyelamatkan masing-masing jiwa.

Kondisi pembatasan sosial atau physical distancing dapat memicu tekanan psikologis, apalagi saat ini masyarakat diliputi kecemasan karena ketidakpastian kapan pandemi ini berakhir. Tidak bebasnya dalam melakukan rutinitas dapat meningkatkan stres. Kerap kali banyak keluhan yang terlontar melalui media sosial mengenai betapa jenuhnya masyarakat untuk tetap berada di bawah atap. Terlebih dengan adanya kegelisahan akan ketidakpastian kondisi yang menyerang pikiran, ini dapat memicu munculnya stres. (Roziika et al., 2020)

Pandemi COVID-19 ini berdampak pada penduduk global secara drastis, dan terhadap berbagai aspek kehidupan. Ancaman penyakit ini dihadapi oleh banyak negara, terjadi pada semua kelompok umur, terutama pada kelompok umur tua atau lanjut usia. Lanjut usia menghadapi risiko yang signifikan terkena penyakit virus Corona ini, apalagi jika mereka mengalami gangguan kesehatan seiring dengan penurunan kondisi fisiologi. (Intarti et al., 2021)

Lansia dan orang dengan berbagai gangguan sistemik seperti hipertensi, penyakit jantung, diabetes, asma, dll, berisiko tinggi terkena COVID-19. Kendala mobilitas yang diberlakukan sebagai langkah pencegahan wabah COVID-19 menjadi hambatan konektivitas sosial di kalangan lansia. Isolasi sosial yang diciptakan telah ditemukan untuk meningkatkan tingkat kecemasan secara eksponensial dan masalah perilaku yang dihasilkan di antara orang tua. Orang yang 
berada dalam isolasi sosial dan karantina mengalami kesepian, gejala stres pasca trauma, kebingungan, kemarahan, depresi, dan kecenderungan bunuh diri. (Walarine \& K V, 2020)

Oleh karena itu, langkah-langkah untuk mengurangi stres dan strategi koping yang efektif untuk lansia dan pengasuh mereka sangat penting untuk kesejahteraan fisik dan emosional mereka dan meningkatkan kualitas hidup mereka. (Walarine \& K V, 2020)

\section{Metode}

Metode yang saya gunakan adalah Literature review dimana dilakukan dengan cara menganalisis kajian dan eksplorasi jurnal, text book, maupun ebook yang relevan dan membahas tentang Stress pada Lansia dimasa Pandemi Covid19. Dengan metode ini informasi pembahasan mengenai Stress pada Lansia dimasa Pandemi Covid-19 dapat dihami dan mempelajari bagaimana cara penanganan stress pada lansia dimasa pandemic Covid-19 dengan tepat. Sumber yang digunakan bersifat subjektif yaitu proses penulisan yang lebih fokus pada landasan teori. Dan melakukan analisis buku dan e-jurnal yang relevan dan berfokus kepada pengaplikasian berfikir kritis dalam mengelola informasi dan komunikasi keperawatan. Sumber yang digunakan adalah sumber yang diterbitkan di 2 tahun terakhir dan referensi akan dicantumkan dibagian daftar pustaka.

\section{Hasil}

Pandemi virus korona SARS-CoV2 yang baru menyapu dengan cepat ke seluruh dunia, tidak diragukan lagi menimbulkan dampak psikologis yang sangat besar pada komunitas. Beberapa dari dampak ini dapat dikaitkan dengan peningkatan kadar stres atau kecemasan. Ada kekhawatiran yang pasti, epidemi penyakit mental sebenarnya bisa terjadi di di tengah pandemi COVID-19 saat ini dan memengaruhi semua generasi dan semua kelompok mayoritas dan minoritas sekalipun berbeda.

Sebenarnya perubahan emosi, seperti khawatir, cemas dan stres merupakan respon biasa ketika menghadapi situasi pandemi. Hal itu merupakan bentuk mekanisme pertahanan diri atau tanda bahwa ada ancaman yang kita hadapi. Namun, apabila berlebihan, maka akan menganggu kondisi psikologis individu, seperti mengalami depresi. Menurut penulis, secara umum kondisi psikologis pada masa pandemi, masih dalam tataran normal. (Agung, 2020)

Para ahli mendefinisikan stress dengan redaksi yang berbeda-beda. Robbins (2001) menyatakan bahwa stres 
merupakan suatu kondisi yang menekan keadaan psikis seseorang dalam mencapai sesuatu kesempatan di mana untuk mencapai kesempatan tersebut terdapat batasan atau penghalang. Weinberg dan Gould (2003) mendefinisikan stres sebagai "a substantial imbalance between demand (physical and psychological) and response capability, under condition where failure to meet that demand has importance concequences". Artinya, ada ketidakseimbangan antara tuntutan (fisik dan psikis) dan kemampuan memenuhinya. Gagal dalam memenuhi kebutuhan tersebut akan berdampak krusial. (Moh, 2020)

Orang tua cenderung kurang familiar dengan teknologi komunikasi. Hal ini menimbulkan kurangnya kontak dengan keluarga. Pembatasan jarak fisik dapat berujung menjadi pembatasan kontak emosional dan kasih sayang jika hal ini tidak ditangani dengan baik (Banerjee, 2020). (Yuliana, 2020)

Hasil studi Brooks, dkk (200) pada 24 artikel tentang dampak karantina wilayah menunjukkan sebagian besar penelitian yang diulas melaporkan efek psikologis negatif termasuk gejala stres pasca-trauma, kebingungan, dan kemarahan. Stresor termasuk durasi karantina yang lebih lama, ketakutan akan infeksi, frustrasi, kebosanan, persediaan yang tidak memadai, informasi yang tidak memadai, kerugian finansial, dan stigma. (Agung, 2020)

Stres lansia terjadi sebagai akibat kecemasan lansia karena lansia rentan terserang berbagai penyakittermasuk Covid-19 yang disebabkan oleh virus Corona (Satgas Covid, 2020). Kecemasan yang merupakan salah satu gejala stres lansia dalam menghadapi situasi dalam pandemi Covid-19 seharusnya mendapat dukungan oleh pasangan dan anggota keluarga, dengan bersedia mendengar keluhan keluhan lansia, mampu dan memiliki waktu untuk selalu dekat dan mendampingi lansia. Anggota keluarga lansia juga bertanggung jawab dan berperan sebagai teman lansia dalam menghadapi hari harinya. Begitu pula dalam stres lansia, terdapat dukungan keluarga untuk memelihara kesehatan dengan melakukan dukungan terhadap kesehatan lansia. (Intarti et al., 2021)

Peningkatan jumlah kasus COVID19 membawa dampak buruk bagi mental semua orang, terlebih orang tua. SARSCoV-2 ini sangat menular. Bahkan beberapa kasus berkembang menjadi gagal napas yang akan berlanjut menjadi kematian. Perburukan kondisi pasien lebih sering dijumpai pada orang usia lanjut dan mereka yang memiliki penyakit penyerta sebelumnya (hipertensi, diabetes, penyakit 
jantung) (Lai et al., 2020; Wang et al., 2020; Yang et al., 2020). Kelompok lanjut usia (lansia) memiliki kelemahan fisik dan psikis pada pandemi COVID-19. Sekitar 20\% kematian penderita COVID-19 di China berusia lebih dari 60 tahun $(\mathrm{Wu} \&$ McGoogan, 2020).

Efek karantina adalah kesepian, kesedihan dan stres berkepanjangan. Penelitian pendahuluan menunjukkan adanya peningkatan depresi, stres pascatrauma, dan gangguan penyesuaian pada usia lanjut. Resiko bunuh diri meningkat tajam (Perrotta et al., 2020). Stres menurunkan kekebalan tubuh. Keadaan ini dapat memperparah kondisi lansia yang memang sudah lemah secara fisik. Pasien yang memiliki kondisi psikiatri sebelumnya akan cenderung mengalami perburukan (Armitage \& Nellums, 2020).

\section{Pembahasan}

Corona virus disease tahun 2019 atau Covid19 adalah jenis baru dari Coronavirus, selain memberikan dampak fisik dapat juga memiliki efek serius pada kesehatan mental seseorang (Huang and Zhao, 2020; Salari, Hosseinian-Far, Jalali, Vaisi-Raygani, Rasoulpoor, Mohammadi, Rasoulpoor and Khaledi-Paveh, 2020). Semenjak Desember 2019, Corona Virus
Disease 2019 (COVID-19) menjadi fokus utama dunia. (Handayani et al., 2020)

Wabah virus COVID-19 ditetapkan sebagai pandemi global oleh WHO karena tingkat persebarannya yang tinggi, massif dan menjangkit penduduk di berbagai negara. Persebaran yang begitu cepat, selain karena sifat dari COVID-19 yang mudah bertransmisi dari orang satu ke orang lain, juga terdapat peranan perilaku masyarakat itu sendiri. Tingkat penyebaran virus apakah tinggi atau tidak, menjadi sebagai suatu prediktor yang menunjukkan indikasi tipe budaya. Variasi budaya pada masyarakat global yang terwakilkan dalam dua domain besar, kolektifis dan individualis mempunyai karakteristik masing-masing terhadap pandemi. Kolektifis mempunyai kecenderungan tingkat penyebaran virus yang tinggi daripada individualis, walaupun perilaku masyarakat kolektifis lebih adaptif daripada masyarakat individualis di dalam menahan laju penyebaran virus.

\section{Penularan COVID-19 diketahui} melalui suatu droplet atau medium perantara yang mengandung virus seperti batuk atau bersin, sehingga memungkinkan berpindah dari orang satu ke orang yang lain (Huang, Wang \& Li et al., 2020). Transmisi COVID-19 yang demikian bisa terjadi ketika individu yang dalam masa inkubasi atau masa dengan 
atau bahkan tanpa gejala, atau sentuhannya yang mengandung droplet virus pada permukaan benda, kemudian orang lain tanpa sengaja menyentuh permukaan yang sama, dan tanpa sadar menyentuh area wajah yaitu mata, hidung dan mulut (Weber et al dalam Qu, G., Li, X., Hu, L., \& Jiang, G., 2020).

Covid-19 merupakan penyakit menular yang berpotensi menimbulkan kedaruratan kesehatan masyarakat. Oleh sebab itu, tindakan pencegahan terhadap jenis penyakit menular tersebut wajib dilakukan secepat mungkin.

\section{Kondisi pandemi Covid-19} menyebabkan sebagian orang merasa khawatir atau takut yang berlebihan dan berpikir yang tidak masuk akal. Tidak jarang mereka memiliki kecurigaan dan prasangka pada orang yang memiliki tanda-tanda penderita Covid-19. Hal tersebut semakin membuat orang semakin berusaha mencari berita mengenai Covid19, dan tidak dapat memilah berita yang akurat sehingga memunculkan kecemasan. Keadaan demikian membuat seseorang mengalami sulit tidur, sakit kepala, dan gangguan fisik lainnya. Inilah yang disebut kondisi stress.

Berbagai gangguan psikologis telah dilaporkan dan dipublikasikan selama wabah Covid-19 salah satunya adalah stres. Stres tidak hanya dirasakan masyarakat bahkan tenaga kesehatan dan semua orang yang bekerja di bidang medis. Gangguan psikologis memiliki dampak yang lebih luas dan lebih lama dibandingkan dengan cedera fisik, sedangkan perhatian pada kesehatan mental jauh lebih sedikit.

Identifikasi individu pada tahap awal gangguan psikologis membuat strategi intervensi lebih efektif. Krisis kesehatan pandemi Covid-19 menyebabkan perubahan psikologis seperti ketakutan, kecemasan, depresi, atau ketidakamanan. Gangguan ini tidak hanya dirasakan oleh tenaga kesehatan atau semua orang yang bekerja di bidang medis, tetapi juga seluruh warga negara (Zhang, Huipeng, Haiping, Shining, Qifeng, Tingyun and Baoguo, 2020). Penelitian terbaru melaporkan bahwa orang dengan pengalaman isolasi dan karantina memiliki perubahan signifikan pada tingkat kecemasan, kemarahan, kebingungan, dan stres. Masyarakat diluar tempat karantina mengalami ketakutan tertular karena pengetahuan tentang Covid19 yang terbatas atau salah (Brooks, Rebecca, Smith, Woodland, Wessely, Greenberg, and Rubin, 2020).

Teori mengenai stress terus berkembang setiap jamannya, namun secara fundamental, teori stress dibangun 
dalam 3 pendekatan (Bartlett, 1998; Lyon, 2012; Lumban Gaol, 2016).: Stres model stimulus (rangsangan), dengan kata lain stress ini merujuk pada hal-hal yang diterima langsung oleh individu tanpa adanya penilaian (Staal, 2004). Bartlett (1998) menegaskan bahwa stres ini lebih fokus pada sumber stres dari pada sumber lainnya. Sumber stress (stressor) dikategorikan berdasarkan tiga jenis yaitu (1) life events (peristiwa kehidupan) adalah perubahan besar yang memerlukan perilaku adaptasi dalam periode waktu yang relative singkat (misalnya kelahiran anak pertama, perceraian), (2) chronic strain (ketegangan kronis) merupakan tuntutan yang berulang juga membutuhkan penyesuaian kembali dalam waktu lama (misalnya melumpuhkan cidera, kemiskinan, masalah perkawinan), dan (3) daily hassles (permasalahan-permasalahan sehari-hari) yang merujuk kepada peristiwa kecil yang memerlukan penyesuaian perilaku kecil selama waktu yang singkat (misalnya kemacetan lalu lintas, pengunjung tak terduga, makan enak) (Thoits, 1995). (Aufar \& Raharjo, 2020)

Stres model response (respon), Selye (1950) mendefisinikan stress ini sebagai hasil inividu merespon stimulus yang diberikan atau reaksi tanggapan tubuh terhadap penyebab stress yang mempengaruhi seseorang. Contoh stres ini apabila seseorang merasakan keadaan yang mengkhawatirkan, ancaman yang muncul kemudian direspon spontan oleh tubuh. Ancaman merupakan sumber stres, respon tubuh merupakan stres respon (Scheneidrman, Ironson \& Siegel, 2005; Lumban Gaol, 2016).

$$
\text { Stres model transactional }
$$
(transaksional) yaitu sebagai penilaian dari individu terhadap suatu penyebab stres yang kemudian akan menentukan respon individu tersebut (Lumban Gaol, 2016; Staal, 2004). Berdasarkan adanya tuntutantuntutan yang timbul terhadap kondisi kesehatan, individu secara khusus menilai atau mengevaluasinya (Lyon, 2012).

Stres semasa pandemi ini adalah penyampaian sugesti yang kuat agar dapat diterima dengan baik oleh klien atau siapapun yang melaksanakan kegiatan tersebut. Kesenjangan sosial ekonomi akibat kehilangan pekerjaan dan hambatan sistemik lainnya dapat memperburuk kesehatan mental masalah di antara populasi umum di tengah COVID-19. Dalam hal ini, pertimbangan utama harus diberikan tentang cara menjamin akses dan kontinuitas layanan orang dengan kondisi kesehatan mental. Sementara, melindungi kesejahteraan mental, orang dengan COVID-19, dan populasi umum 
merupakan pekerjaan orang-orang yang berada di garis terdepan.

Penelitian terbaru melaporkan bahwa orang dengan pengalaman isolasi dan karantina memiliki perubahan signifikan pada tingkat kecemasan, kemarahan, kebingungan, dan stres. Masyarakat diluar tempat karantina mengalami ketakutan tertular karena pengetahuan tentang Covid-19 yang terbatas atau salah (Brooks, Rebecca, Smith, Woodland, Wessely, Greenberg, and Rubin, 2020).

Pada sisi lain, stress dialami oleh anggota keluarga yang sakit dan yang meninggal karena Covid-19. Protokol Kesehatan yang harus ditaati mengakibatkan tekanan tersendiri bagi penderita dan keluarga yang tidak bisa merawat secara langsung. Demikian juga dengan keluarga yang meninggal karena terkena virus corona, akan mendapatkan tekanan tersendiri dari lingkungan sekitar, karena khawatir tertular. (Moh, 2020)

Menurut laporan WHO dapat dilihat bahwa 8 dari 10 kematian terjadi pada individu dengan setidaknya satu komorbiditas, khususnya mereka dengan penyakit kardiovaskular, hipertensi dan diabetes mellitus, tetapi juga dengan berbagai kondisi kronis lainnya (Kemenpemberdayaan perempuan dan perlindungan anak RI, 2020). Selain sistem imun, tidak sedikit lansia yang memiliki penyakit kronis, seperti penyakit jantung, diabetes, asma, atau kanker. Hal ini bisa meningkatkan risiko atau bahaya infeksi virus Corona. Dan komplikasi yang timbul akibat COVID-19 juga akan lebih parah bila penderitanya sudah memiliki penyakit-penyakit tersebut (Nareza, 2020)

Pandemi COVID-19 telah mengubah seluruh kehidupan kita, terutama lansia. Semua kegiatan harus dilakukan di rumah. Hal ini membuat lansia merasa terisolasi dan terkurung, terlebih mereka yang ada di panti jompo. Depresi, cemas, dan insomnia akan muncul. Lansia yang memiliki penyakit penyerta seperti hipertensi dan diabetes melitus cenderung mengalami perburukan gejala COVID-19. Gagal napas sering terjadi pada penderita lansia. Tujuan tinjauan pustaka ini adalah memberikan pengetahuan mengenai bagaimana menjaga kesehatan mental lansia selama masa pandemi COVID19. Lansia sering terabaikan pada masa pandemi ini. Menjaga kesehatan mental lansia selama pandemi COVID-19 memerlukan bantuan dari semua pihak. (Yuliana, 2020)

Keluarga, petugas kesehatan, pemerintah, dan lansia itu sendiri wajib bekerja sama. Pengetahuan, sikap, dan perilaku lansia harus ditingkatkan dalam 
menghadapi kondisi pandemi COVID-19 ini. Adaptasi dan bertahan itulah kunci mengatasi kondisi pandemi ini. Menjaga jarak fisik, mencuci tangan, menggunakan masker, mengonsumsi makanan bergizi, dan berolahraga ringan wajib dilakukan secara rutin. Hobi yang bisa dilakukan dalam ruangan seperti membaca buku, melukis, maupun menonton film juga merupakan aktivitas yang baik. Penjelasan harus diberikan seringkas mungkin kepada lansia. Jika lansia mengerti, maka mereka akan merasa aman dan damai. Kualitas hidup akan meningkat.

Hubungan sosial dengan keluarga dan sahabat melalui alat komunikasi harus tetap dipertahankan. Dukungan emosional sangat penting untuk lansia yang hidup sendirian. Pemerintah hendaknya menyediakan layanan konseling telepon secara gratis untuk masyarakat, terutama lansia. Keluarga dan tetangga hendaknya saling menjaga lansia yang tinggal di dekat mereka. Karena kebutuhan psikososial amat penting bagi lansia.

kontak emosional dan kasih sayang jika hal ini tidak ditangani dengan baik (Banerjee, 2020). Keadaan emosional pasien demensia akan lebih tidak stabil dibandingkan dengan lansia pada umumnya. Mereka akan merasa terkurung, bingung, bahkan takut. Kunjungan anak dan saudara akan jauh berkurang. Di saat inilah para lansia harus berusaha belajar memakai alat komunikasi untuk kontak dengan sanak saudara untuk mengurangi kesepian. Pada pasien dengan demensia, komunikasi harus lebih diperhatikan (Banerjee, 2020).

Untuk memerangi masalah kesehatan mental COVID-19, beberapa settings telah menggunakan perawatan digital dan solusi pencegahan untuk mencapai skala yang diinginkan. Dalam kesehatan mental virtual tertentu layanan telah bekerja dengan baik dalam menangani skala dan membatasi pajanan pasien terhadap COVID-19 di fasilitas kesehatan.

Sebelum mengelola stress perlu diketahui terlebih dahulu gejala-gejala Stress lansia pada masa Pandemi Covid19. Di antara tanda-tandanya antara lain: 1. memiliki rasa khawatir atau takut yang berlebihan sehingga berpikir yang tidak rasional 2. memiliki pikiran negatif terhadap orang yang memiliki tanda-tanda penderita 3. mencari berita mengenai Covid-19 yang berlebihan sehingga tidak dapat memilah berita yang akurat dan dapat memunculkan kecemasan yang membuat seseorang mengalami sulit tidur 4. sakit kepala, serta sakit fisik lainnya. (Moh, 2020) 
Berikut langkah-langkah yang ditawarkan dalam mengelola stress:

\section{Mengenali Penyebab Stress di Masa Pandemic Covid-19}

Di saat pandemi ini yang menjadi sumber stress (stressor) adalah berita mengenai Covid-19 dan pembatasan sosial yang dilakukan oleh pemerintah. Oleh sebab itu masyarakat dituntut untuk bijak dalam membaca berita. Harus dari sumber yang valid karena sering kali berita hoax yang ada. Informasi yang ada harus dipilih dan dipilah. Mencari informasi dari sumber yang terpercaya, adalah salah satu solusi, tidak gampang percaya berita-berita yang mengakibatkan semakin cemas, khawatir dan gelisah. Karena mempercayai berita yang membuat kecemasan, kekhawatiran dan kegelisahan menjadi salah satu pemicu stress.

\section{Mengendalikan Stress}

Tekanan yang dihadapi seseorang tidak hanya menimbulkan stress yang negatif (distress), akan tetapi bisa juga menjadi stress yang positif (eusstres). Butuh pengendalian jiwa yang matang (dewasa) agar kondisi yang ada menjadi hal yang positif. Disinilah perawat bisa memberikan edukasi dan mengajak pasien agar tetap tenang. Dan bisa juga melakukan konsul terkait dengan rasa cemas dan stress yang dialami para lansia.

\section{Mengatasi stress (stress coping)}

Stress dapat mempengaruhi kondisi fisik, mental dan emosi seseorang. Maka dari itu penting bagi setiap orang untuk memiliki pengetahuan dan kemampuan dalam mengatasi stress. Dengan memahami teori dan konsep stress, seseorang dapat memiliki kuasa penuh dalam mengontrol diri dan emosinya sehingga ia dapat mengoptimalkan kemampuan dan kekuatan yang dimilikinya. (In The Know:2014) Yang perlu ditekankan juga dalam mengatasi stress ialah bahwa kita tidak memiliki kendali terkait penyebab stress, tetapi kita mampu mengontrol bagaimana kita bereaksi terhadap stress tersebut. (U.S. Department of Veterant Affairs,: 2014)

Dengan ketidakpastian dan situasi yang semakin memburuk yang diakibatkan oleh COVID-19, terdapat beberapa rekomendasi dalam mengatasi kesehatan mental selama pandemi dan juga bencana berskala besar (Ornell, Schuch, Sordi, \& Kessler, 2020, p. 233) seperti:

1) Menjaga diri dan orang lain, tetap berhubungan dengan teman dan keluarga

2) Membatasi paparan berita terkait COVID-19, karena terlalu banyak informasi dapat memicu gangguan kecemasan

3) Senantiasa mengikuti anjuran kesehatan dari World Health 
Prganization (WHO) dan Dinas Kesehatan.

4) Beritahu seseorang (yang dipercaya) jika memiliki gejala cemas dan merasa sedih

5) Memperhatikan kebutuhan, perasaan/emosi, dan pikiran diri sendiri

6) Membatasi kontak fisik dengan orang lain sembari menghindari jarak emosional

7) Memantu kondisi mental diri sendiri, dan memahami bahwa stres dan rasa takut merupakan perasaan normal di situasi yang tidak kita ketahui

8) Mempertahankan pola tidur, pola makan, dan olahraga yang baik dan teratur

9) Meditasi

10) Tetap mengikuti anjuran penggunaan obat secara normal, serta penggunaan tekni-teknik positif dari psikiater atau psikolog.

Berbagai Strategi Menjaga Kesehatan Mental Lansia Selama Pandemi COVID19:

Menjaga kesehatan mental lansia selama pandemi COVID-19 memerlukan bantuan dari semua pihak. Keluarga, petugas kesehatan, pemerintah, dan lansia itu sendiri wajib bekerjasama. Yang harus ditingkatkan adalah pengetahuan, sikap, dan perilaku lansia menghadapi kondisi pandemi COVID-19 ini. Adaptasi dan bertahan itulah kunci mengatasi kondisi pandemi ini (Perrotta et al., 2020). Strategi yang dianggap penting untuk dilakukan adalah memastikan lansia selalu menjaga jarak fisik, mencuci tangan, menggunakan masker, mengonsumsi makanan bergizi, dan berolahraga ringan. Hobi yang bisa dilakukan dalam ruangan seperti membaca buku, melukis, maupun menonton film bisa tetap dilakukan. Penjelasan harus diberikan seringkas mungkin kepada lansia. Jika lansia mengerti, maka mereka akan merasa aman dan damai. Kualitas hidup akan meningkat. Hubungan sosial dengan keluarga dan sahabat melalui alat komunikasi harus tetap dilakukan. Dukungan emosional sangat penting untuk lansia yang hidup sendirian. Mereka rentan akan kecemasan dan kebingungan selama periode yang tidak menentu ini (Banerjee, 2020).

Kunjungan ke dokter hendaknya digantikan dengan telemedicine. Artinya pasien dapat berkonsultasi melalui whatsapp messenger, telepon, pesan singkat, Zoom, atau aplikasi apapun. Semua pembedahan berencana seperti katarak, hernia, dan penggantian tempurung lutut hendaknya ditunda (Banerjee, 2020). Segala informasi yang berlebihan mengenai COVID-19 hendaknya dikurangi. Hal ini untuk 
mencegah panik dan kesalahpahaman. Informasi hendaknya difokuskan pada tindakan pencegahan, bukan berdasarkan mitos saja. Informasi kesehatan, update seputar COVID-19, dan konsultasi psikologi hendaknya disediakan melalui telepon ataupun online oleh pemerintah (Banerjee, 2020).

Walaupun lansia terlihat lemah dari luar, namun keluarga harus berusaha memberikan rasa kebebasan, hormat, dan perhatian yang tulus bagi mereka. Lansia tetap harus dilibatkan dalam pengambilan keputusan. Organisasi Kesehatan Dunia (World Health Organization, WHO) menekankan pentingnya kebutuhan psikososial bagi lansia (Banerjee, 2020).

Pemerintah diharapkan dapat menyediakan kebutuhan pokok bagi para lansia terutama mereka yang kurang mampu secara finansial dan psikologis. Hal-hal yang penting disiapkan adalah makanan, obatobatan, maupun desinfektan. Kebutuhan akan rasa aman termasuk hal penting dan tak boleh diabaikan (Perrotta et al., 2020).

\section{Penutup}

\section{Kesimpul}

Pandemi COVID-19 membuat dunia terhenti. Sejak awal 2020, sosial hidup telah berubah bagi banyak orang di seluruh dunia. Pembatasan pemerintah dan norma sosial baru menyebabkan penurunan mobilitas (Google, 2020), penghindaran transportasi umum, pembatalan sebagian besar acara besar seperti konser, festival, acara keagamaan dan olahraga, dan penutupan sementara dari pertemuan tempat-tempat seperti kafe, restoran, museum atau teater. (Kowal et al., 2020) Wabah COVID-19 dan tindakan yang diambil oleh hampir semua negara di dunia berbagai ancaman terhadap kesejahteraan psikologis orang; jadi, kami percaya itu fokus pada lingkungan sosial terdekat kita sangat dibutuhkan. Keduanya relatif kurang hubungan sosial (Tay et al., 2013) dan emosi negatif (Huppert, 2009).

Sangat memprediksi kematian secara keseluruhan dan hasil penyakit, dan ancaman SARSCoV-2 dapat meningkatkan tingkat kecemasan (Karwowski et al., 2020) dan prasangka terhadap kebangsaan lain (Sorokowski et al., 2020), melakukan segala upaya untuk memahami stres pada individu yang terisolasi atau dikarantina selama COVID19 pandemi bahkan lebih penting. Apalagi untuk memahami kemungkinan negatif efeknya, penting untuk membongkar faktor-faktor yang sudah ada sebelumnya yang dapat memprediksi stres tingkat orang di karantina atau isolasi.

Menjaga kesehatan mental lansia selama pandemi COVID-19 memerlukan 
bantuan dari semua pihak. Keluarga, petugas kesehatan, pemerintah, dan lansia itu sendiri wajib bekerjasama. Pengetahuan, sikap, dan perilaku lansia harus ditingkatkan dalam menghadapi kondisi pandemi COVID-19 ini. Adaptasi dan bertahan itulah kunci mengatasi kondisi pandemi ini. Menjaga jarak fisik, mencuci tangan, menggunakan masker, mengonsumsi makanan bergizi, dan berolahraga ringan. Hobi yang bisa dilakukan dalam ruangan seperti membaca buku, melukis, maupun menonton film bisa tetap dilakukan. Penjelasan harus diberikan seringkas mungkin kepada lansia. Jika lansia mengerti, maka mereka akan merasa aman dan damai. Kualitas hidup akan meningkat. Hubungan sosial dengan keluarga dan sahabat melalui alat komunikasi harus tetap dilakukan.

Dukungan emosional sangat penting untuk lansia yang hidup sendirian. Segala informasi yang berlebihan mengenai COVID-19 hendaknya dikurangi. Hal ini untuk mencegah panik dan kesalahpahaman. Informasi hendaknya difokuskan pada tindakan pencegahan, bukan berdasarkan mitos saja. Pemerintah hendaknya menyediakan layanan konseling telepon secara gratis untuk masyarakat, terutama lansia. Keluarga dan tetangga hendaknya saling menjaga lansia yang tinggal di dekat mereka. Mereka dapat mengirimkan makanan maupun obat-obatan rutin ke rumah lansia supaya mereka tidak perlu keluar rumah terlalu sering. Lansia dengan penyakit demensia Alzheimer, depresi, maupun gangguan kejiwaan lain harus dimonitor lebih ketat karena memiliki resiko bunuh diri. Kebutuhan psikososial amat penting bagi lansia. (Yuliana, 2020)

\section{Daftar Pustaka}

Agung, I. M. (2020). Memahami Pandemi Covid-19 Dalam Perspektif Psikologi Sosial. Psikobuletin:Buletin Ilmiah Psikologi, 1(2), 68-84. https://doi.org/10.24014/pib.v1i2.9616

Akaninyene Otu, C. H. (2020). Mental health and psychosocial well-being during the COVID-19 pandemic: the invisible elephant in the room. International Journal of Mental Health Systems, 14(38), 1-5. https://doi.org/10.1186/s13033020-00371-w

Aufar, A. F., \& Raharjo, S. T. (2020). Kegiatan Relaksasi Sebagai Coping Stress Di Masa Pandemi Covid-19. Jurnal Kolaborasi Resolusi Konflik, 2(2), 157-163. https://doi.org/10.24198/jkrk.v2i2.29126

Gokmen, Y., Baskici, C., \& Ercil, Y. (2021). The impact of national culture on the increase of COVID-19: A cross-country 
analysis of European countries.

International Journal of Intercultural

Relations, 81(May 2020), 1-8.

https://doi.org/10.1016/j.ijintrel.2020.12.

006

Handayani, R. T., Kuntari, S., Darmayanti, A.

T., Widiyanto, A., \& Atmojo, J. T.

(2020). FAKTOR PENYEBAB STRES

PADA TENAGA KESEHATAN DAN

MASYARAKAT SAAT PANDEMI

COVID-19. Jurnal Keperawatan Jiwa, $8(3), 353$.

https://doi.org/10.26714/jkj.8.3.2020.353

$-360$

Intarti, W. D., Parmila, N., \& Savitri, H.

(2021). MANFAAT RELAKSASI

YOGA DAN SWEDISH MASSAGE

TERHADAP STRESS LANSIA SAAT

PANDEMI COVID-19. Jurnal Bina

Cipta Husada, 17(1), 96-112.

Kowal, M., Coll-Martín, T., Ikizer, G.,

Rasmussen, J., Eichel, K., Studzińska,

A., Koszałkowska, K., Karwowski, M.,

Najmussaqib, A., Pankowski, D.,

Lieberoth, A., \& Ahmed, O. (2020). Who

is the Most Stressed During the COVID-

19 Pandemic? Data From 26 Countries

and Areas. Applied Psychology: Health

and Well-Being, 12(4), 946-966.

https://doi.org/10.1111/aphw.12234

Levkovich, I., \& Shinan-Altman, S. (2020).

Impact of the COVID-19 pandemic on

stress and emotional reactions in Israel: a

mixed-methods study. International

Health, 1-18. https://doi.org/10.21203/rs.3.rs-30346/v1

Moh, M. (2020). Manajemen Stress pada Masa Pandemi Covid-19. Jurnal Manajemen Bisnis, 23(2), 192-201.

Richard Armitage, L. B. (2020, Maret). COVID-19 and the consequences of isolating the elderly. The Lancet Public Health, 5(5), e256. https://doi.org/10.1016/S24682667(20)30061-X

Roziika, A., Santoso, M. B., \& Zainudiin, M. (2020). Penanganan Stres Di Masa Pandemi Covid-19 Dengan Metode Emotional Freedom Technique (Eft). Focus: Jurnal Pekerjaan Sosial, 3(2), 121-130.

Shrestha, D. B., Thapa, B. B., Katuwal, N., Shrestha, B., Pant, C., Basnet, B., Mandal, P., Gurung, A., Agrawal, A., \& Rouniyar, R. (2020). Psychological distress in Nepalese residents during COVID-19 pandemic: A community level survey. BMC Psychiatry, 20(1), 18. https://doi.org/10.1186/s12888-02002904-6

Telaumbanua, D. (2020). Urgensi

Pembentukan Aturan Terkait Pencegahan Covid-19 di Indonesia. QALAMUNA: Jurnal Pendidikan, Sosial, Dan Agama, 12(01), 59-70. https://doi.org/https://orcid.org/00000001-6207-687

Walarine, M. T., \& K V, B. M. (2020). 
Pandemic effect on the elderly and their caregivers. Journal of Ideas in Health, 3(4), 248-251.

https://doi.org/10.47108/jidhealth.vol3.is s4.76

Yuliana. (2020). Menjaga Kesehatan Mental Lansia Selama Pandemi COVID-19. Journal UIN-Alauddin, 6(1), 6-10. http://journal.uinalauddin.ac.id/index.php/psb/ 